\title{
PENGARUH SELF-COMPASSION, RELIGIUSITAS, SUPPORT GROUP DAN PENDAPATAN TERHADAP SUBJECTIVE WELL-BEING ORANG TUA ANAK TUNAGRAHITA
}

\author{
Risa Dwi Ratnasari \\ Risa.wiratnas@gmail.com \\ Terapis Efthemia
}

\author{
Neneng Tati Sumiati \\ neneng.tati@yahoo.co.id \\ Fakultas Psikologi UIN Syarif Hidayatullah \\ Jakarta
}

\begin{abstract}
Subjective well-being (SWB) is an evaluation of a person's cognitive and affective life. Evaluation of one's life in subjective well-being includes a positive emotional reaction to the occurrence in life, as well as the lack of negative emotional charge of cognition ratings on satisfaction and fulfillment in life (Diener, Lucas, \& Oishi, 2005). This study was condu

cted to determine the influence of self-compassion, religiosity, support group and pendapatan on subjective wellbeing of parents of children with mental retardation. Researcher adapting various instrument such as Diener's SWB instrument (1985; 2010), Neff's self-compassion instrument (2003), and Huber's religiosity instrument (2012). The research method used a non-probability sampling with accidental sampling technique. Participants in this study amounted to 209 parents. The researcher use Confirmatory Factor Analysis (CFA) as construct validity test. The results showed that the four dimensions, namely self-compassion, religiosity, support group and pendapatan has a significant effect on subjective well-being of parents who have children with mental retardation. The proportion of the overall independent variables towards SWB amounted to $28.8 \%$ with four significant variables that self-compassion, religiosity in aspects of religious knowledge, religious experience and household income.
\end{abstract}

Keywords: Subjective well-being, self-compassion, religiosity, support group, income

\begin{abstract}
Abstrak
Subjective Well-Being (SWB) adalah evaluasi kognitif dan afektif seseorang terhadap kehidupannya. Evaluasi kehidupan seseorang dalam subjective well-being mencakup reaksi emosi positif terhadap kejadian dalam hidup, rendahnya muatan emosi negatif sebagaimana penilaian kognisi atas kepuasan dan pemenuhan hidup (Diener, Lucas, \& Oishi, 2005). Penelitian ini dilakukan untuk mengetahui pengaruh self-compassion, religiusitas, affiliasi support group dan pendapatan terhadap subjective well-being orangtua yang memiliki anak dengan tunagrahita. Peneliti mengadaptasi instrumen SWB diener $(1985 ; 2010)$, untuk self-compassion mengadaptasi instrumen Neff (2003), dan untuk religiusitas mengadaptasi instrumen Hubber (2012). Metode penelitian menggunakan nonprobability samplingdengan teknik accidental sampling.Partisipan dalam penelitian ini berjumlah 209 orang tua.Uji validitas konstruk menggunakan tekhnik CFA. Hasil penelitian menunjukan bahwa empat dimensi yakni self-compassion, religiusitas (pengetahuan keagamaan, pengalaman keagamaan), affiliasi support group dan pendapatan memiliki pangaruh yang signifikan terhadap subjective well-being orangtua yang memiliki anak dengan tunagrahita. Proporsi independent variable secara keseluruhan terhadap SWB adalah sebesar $28.8 \%$ dengan empat variabel signifikan yakni self-compassion, religiusitas di aspek pengetahuan keagamaan, pengalaman keagamaan dan pendapatan rumah tangga.
\end{abstract}

Kata kunci: Subjective well-being, self-compassion, religiosity, support group, pendapatan

Diterima: 07 Oktober 2016 Direvisi: 15 November 2016 Disetujui: 21 Desember 2016 


\section{PENDAHULUAN}

Kelengkapan kehidupan berkeluarga akan terasa ketika anak hadir di tengahtengah kehidupan berkeluarga. Pada umumnya dikaruniai anak yang normal adalah harapan bagi orang tua, akan tetapi tidak sedikit kasus dimana orang tua dianugrahkan anak yang berkebutuhan khusus (ABK) dimana salah satu kategorinya adalah tunagrahita. Dalam konteks medis, pendidikan dan sosial, Tunagrahita atau mental retardasi adalah manifestasi dari bermacam-macam kumpulan kerusakan dan kondisi yang menghasilkan keterbatasan kognitif (Jacobson, Mulick, \& Rojahn, 2007). Kelainan yang menjadi penyumbang tunagrahita adalah Down syndrome, Rett syndrome, Fetal alcohol syndrome, Cerebral palsy, Autistic spectrum disorder dan gangguan lainnya yang menyebabkan kerusakan intelektual menjadi kelompok kelainan yang berkontribusi atas penyebab terjadinya tunagrahita (O'Hara, McCarthy, \& Bouras, 2010).

Orang tua yang memiliki anak tunagrahita dihadapan pada kehidupan yang tidak biasa. Ketergangtungan penyandang tunagrahitayang disebabkan keterbatasannya membuat tuntutan pengasuhan yang berdampak langsung baik pada psikologis dan kesehatan fisik dari pengasuh (Raina \& Donnell, 2005). Terlebih lagi perilaku maladaptive yang dimunculkan oleh penyandang tunagrahita membuat kondisi stres tersendiri bagi orang tua yang memiliki anak tunagrahita Berdasarkan penelitian komparasi Subjective well-being (SWB)antara orangtua yang memiliki anak dengan tunagrahita dan orangtua yang memiliki anak normal menunjukan adanya perbedaan yang signifikan pada subjective wellbeing orangtua, dimana skor depresi dan kecemasan yang lebih tinggi yang mengakibatkan rendahnya skor subjective well-being pada orang tua yang memiliki anak dengan tunagrahita di bandingkan orang tua yang memiliki anak normal (Boromand, Narimani, \& Mosazadeh, 2014).

Subjective well-being didefinisikan sebagai evaluasi kognitif dan afektif seseorang terhadap kehidupannya. Evaluasi kehidupan seseorang dalam subjective well-being mencakup reaksi emosi positif terhadap kejadian dalam hidup, rendahnya muatan emosi negatif sebagaimana penilaian kognisi atas kepuasan dan pemenuhan hidup (Diener, Lucas, \& Oishi, 2005). Subjective well-being (SWB) terfokus dengan bagaimana dan mengapa orang menjalani kehidupan mereka dengan cara yang positif. Termasuk dalam penilaian kognitif dan reaksi afektif (Diener, 1984).

Kehidupan yang penuh dengan tekanan seringkali berdampak pada rendahnya subjective well-beingorang tua yang memiliki anak tunagrahita. Dalam sebuah penelitian menujukan sres yang dialami orangtua dan depresi pada anak tunagrahita berdampak sangat kuat pada rendahnya Psychological well-being pada orangtua sebagai pengasuh penyandang tunagrahita (Cramm \& Nieboer, 2011).

Pada studi awal yang dilakukan peneliti pada sejumlah orang tua yang memiliki anak dengan tunagrahita tahun 2016, didapatkan mayoritas respon yang mencerminkan perasaan negatif atas kehadiran anak dengan tunagrahita. Perasaan negatif yang dirasakan adalah seperti kesedihan, kebingungan, kegelisahan, dan rasa terkejut. Ada pula yang menjelaskan kekhawatiran akan masa depan anak dan kemandirian disaat orang tua telah tiada serta kegelisahan karena anak menjadi bahan cemoohan di lingkungan rumah. 
Kondisi SWB yang rendah pada orangtua tentu sangat tidak baik bagi kelangsungan hidup dan pengasuhan anak dengan tunagrahita karena orangtua adalah penyedia utama atas dukungan untuk anak-anak dengan tunagrahita , menjaga kesehatan dan kesejahteraan jiwa yang baik pada orangtua merupakan syarat agar dapat memberikan perawatan yang optimal untuk anak-anak (Benjak, Mavrinac, \& Śimetin, 2009). Oleh karena pentingnya subjective well being pada orang tua yang memiliki anak tunagrahita maka interaksi berbagai faktor perlu diketahui dan dipertimbangkan untuk mengurangi beban orangtua dengan anakanak dengan tunagrahita (Nikmat, Ahmad, Oon, \& Razali, 2008). Dimana interaksi berbagai faktor tersebut diharapkan dapat meningkatkan subjective wellbeing orangtua dengan anak-anak tunagrahita.

Dari hasil Neff (2014) mengenai subjective well-being, terdapat faktor-faktor yang berperan dalam peningkatan skor subjective well-being pada individu. Faktor yang berkontribusi terhadap subjective well-being adalah self-compassion, Selfcompassion dapat dipahami sebagai strategi regulasi emosi individu dalam menghadapi situasi sulit melalui kesadaran yang menyertai rasa kasih sayang terhadap diri, pemahaman, dan keterbukaan dengan lingkungan (Neff,2003).

Meskipun tergolong istilah baru di dunia psikologi namun pada beberapa penelitian, self-compassion terbukti meningkatkan kondisi well-being pada individu. Berdasarkan Pada penelitian well-being padaorangtua anak dengan ASD (Autism Spectrum Disorder) menunjukan adanya hubungan positif yang signifikan antara tingginya level self-compassion dan baiknya kesejahteraan (well-being) pada orangtua anak dengan gangguan autis. Dalam penelitian yang sama juga dikemukakan bahwa "pengasuhan dan dukungan yang disertai dengan selfcompassion dapat membantu orangtua mengurangi kelelahan dalam menghadapi tatangan membesarkan anak dengan gangguan autis (Neff \& Faso, 2014).

Selanjutnya faktor yang dapat meningkatkan subjectivewell-being adalah religiusitas. Teori religiusitas pada penelitian ini lebih mengacu pada teori yang dikembangkan oleh Stefan Huber dan Odilo Huber (2012) di mana religiusitas dijabarkan ke dalam lima dimensi yaitu pengetahuan, sistem belief, perasaan, aktivitas keagamaan baik itu yang bersifat individu maupun kelompok, dan pengalaman keagamaannya (Stefan Huber \& Odilo Huber, 2012). Berdasarkan penelitian Witter, Stock, Okun dan Haring (1985) religiusitas dan variabel subjective well-being bahwa religiusitas secara positif memiliki hubungan yang signifikan terhadap subjective well-being pada orang dewasa di US (Witter, Stock, Okun, \& Haring, 1985).

Kemudian menjadi anggota dari sebuah support group yang memiliki kesamaan kondisi yakni memiliki anak berkebutuhan khusus juga dapat berkontribusi terhadap subjective well-being orangtua yang memiliki anak dengan tunagrahita. Dilaporkan orangtua yang berpartisipasi dalam support group diketahui memiliki coping yang lebih adaptif dan kepuasaan dalam menerima manfaat informasiyang lebih tinggi signifikan dibanding orangtua yang tidak berpartisipasi dalam support group (Clifford, 2011).

Dari hasil studi awal pada sampel yang sama, didapatkan tanggapan positif dari dampak yang dirasakan atas keikutsertaan orang tua dalam support group anak dengan tunagrahita. Tanggapan positif yang diberikan antara lain 
membuat pikiran menjadi lebih sehat, tidak merasa sendiri, tenang dan senang. Dijelaskan lebih lanjut oleh beberapa orang tua bahwa keikutsertaan dalam support group membuat orang tua memiliki tempat saling berbagi suka dan duka tentang anak, lebih mudah menghadapi masalah anak, merasa memiliki banyak teman dan tidak lagi perlu merasa malu memiliki anak dengan tunagrahita.

Sejalan dengan literatur di atas pada peninjauan yang dilakukan peneliti kepada orang tua yang memiliki anak dengan tunagrahita juga menunjukan hampir keseluruhan tanggapan positif atas keikutsertaan orang tua dalam support group. Di sisi lain faktor keuangan keluarga juga menjadi faktor yang dapat meningkatkan subjective well-being.Seperti yang ditemukan dalam penelitian adhityani (2014) bahwa pendapatan atau pendapatan merupakan salah satu variabel yang memiliki pengaruh signifikan terhadap subjective wellbeing pada orang tua yang memiliki ASD (Autism Spectrum Disorder) (Adhityani, 2014).

Dari berbagai faktor yang mempengaruhi subjective well-being dalam penelitian ini Peneliti memutuskan untuk fokus pada variabel self-compassion sebagai prediktor pertama dimana di dalam variabel self-compassion terdapat tiga dimensi yakni self-kindness, common humanity, dan mindfulness kemudian religiusitas sebagai prediktor kedua dengan dimensipengetahuan keagamaan, keyakinan keagamaan, kegiatan keagamaan kelompok, kegiatan keagamaan individu pengalaman keagamaan. Kemudian support group yang berasal dari teori besar dukungan sosial, variabel ini masuk kedalam variabel demografi dengan pilihan respon : iya $=$ mengikuti support group dan tidak $=$ tidak mengikuti support groupdan jumlah pendapatan rumah tangga dalam kurun waktu satu bulan.

Peneliti bersumsi orang tua yang memiliki self-compassion yang tinggi, keyakinan agama yang baik dan ikut sertanya orang tua dalam kelompok atau komunitas dukungan khusus akan mengakibatkan tingginya subjective wellbeing, juga tingginya pendapatan rumah tangga yang berdampak pada hadirnya penilaian positif dan kepuasaan hidup orang tua terhadap kehidupanya maka peneliti memutuskan untuk mengangkat judul "Pengaruh Self-compassion, Religiusitas, Support Group dan pendapatan terhadap Subjective well-being Orang Tua Anak Tunagrahita".

\section{METODE PENELITIAN}

Populasi, sampel dan teknik pengambilan sampel

Populasi dalam penelitian ini yaitu orang tua anak dengan tunagrahita yang bertempat tinggal di Jakarta dan Tanggerang berjumlah 230 orang kemudian melalui proses elisitasi didaptakan data partisipan sejumlah 209 orang. Ada pun karakteristik sampel sebagai berikut:

1. Orang tua laki-laki atau perempuan yang memiliki anak dengan tunagrahita.

2. Memiliki anak dengan tunagrahita dalam rentang usia balita hingga SMP.

3. Berdomisili di Tangerang dan Jakarta.

4. Memiliki satu orang anak dengan tunagrahita.

Peneliti mengggunakan teknik non probability sampling, yaitu accidental sampling. 


\section{Instrumen penelitian}

Terdapat empatskala ukur baku dan dua informasi demografis yang digunakan peneliti dalam penelitian ini, yaitu :

1. Alat ukur Subjective well-being

Pada pengukuran subjective well-being,peneliti menggunakan dua skala yang diadaptasi yakni untuk pengukuran aspek kognitif peneliti menggunakan Diener, et.al (1985) SWLS (Satisfaction With Life Satisfaction Scale) terdiri dari 5 item bersifat favorable dan untuk aspek afektif peneliti menggunakan Diener et. al (2009) SPANE (Scale of Postisive and Negative Experience)terdiri dari 12 item dimana 6 item mengukur afek positif dan 6 item mengukur afek negatif.

\section{Alat ukur self-compassion}

Pada pengukuran self-compassion peneliti mengadaptasi self-compassion scale yang diciptakan oleh Neff (2003) berisi 26 item terdiri atasitem favorable dan unfavorable dengan rincian 10 item untuk mengukur self-kindness vs selfjudgement, 8 item untuk mengukur common humanity vs isolation, dan 8 item untuk mengukur mindfulness vs over-identification.

\section{Alat Ukur Religiusitas}

Pada pengukuran religiusitas peneliti mengadaptasi CRS ( Central Religious Scale) yang dikembangkan oleh Stefan Huber dan Odilo Huber (2012) berisi 15 item terdiri atas item favorable dengan rincian 3 item mengukur pengetahuan keagamaan, 3 item mengukur keyakinan keagamaan, 3 item mengukur kegiatan keagamaan kelompok, 3 item mengukur kegiatan keagamaan individu, 3 item mengukur pengalaman keagamaan.

4. Pengukuran variabel demografi (support group dan pendapatan)

Pada pengukuran variabel support group dan pendapatan,partisipan diarahkan untuk mengisi data demografis di lembar skala penelitian.

\section{HASIL PENELITIAN}

\section{Gambaran Partisipan Penelitian}

Pada penelitian ini peneliti mengambil partisipan orang tua yang memiliki anak dengan tunagrahita di wilayah Jakarta dan tanggerang selatan. Data partisipan yang berhasil diperoleh dan dimasukan dalam analisis hasil sebanyak 209 data. Berdasarkan tabel berikut diketahui bahwa responden penelitian yang berjenis kelamin laki-laki berjumlah 68 orang atau 33\%, sementara itu terdapat 141 orang atau $67 \%$ reponden penelitian yang berjenis kelamin perempuan. Selanjutnya akan data anak dengan tunagrahita berdasarkan urutan kelahiran urutan keahiran ke-satu berjumlah 70 orang atau 33.49\%, urutan kelahiran ke-dua berjumlah 77 orang atau $36.84 \%$, urutan kelahiran ke-tiga berjumlah 46 orang atau 22.00 , urutan kelahiran ke-empat berjumlah 13 orang atau $6.25 \%$, selanjutnya urutan kelahiran ke-lima berjumlah 2 orang atau $0.95 \%$ dan urutan kelahiran ke-tujuh berjumlah 1 atau $0.47 \%$.

\section{Tabel 1}




\begin{tabular}{lll}
\hline & & $\sum N=209$ \\
\hline Data Demografi & $\mathrm{N}$ & $(\%)$ \\
\hline $\begin{array}{l}\text { Data Orang tua } \\
\text { Jenis kelamin }\end{array}$ & & \\
Perempuan & 68 & 33 \\
Laki-laki & 141 & 67 \\
Tingkat pendapatan (Rp) & & \\
$<1000.000$ & 13 & 6 \\
1000.000-2000.000 & 67 & 32 \\
3000.000-4000.000 & 74 & 36 \\
5000.000-6000.000 & 30 & 14 \\
$>7000.000$ & 25 & 12 \\
Keikutsertaan support group & & \\
Mengikuti & 114 & 55 \\
Tidak mengikuti & 95 & 45 \\
Data anak dengan tunagrahita & & \\
Urutan kelahiran & & \\
Ke-satu & 70 & 33,49 \\
Ke-dua & 77 & 36.84 \\
Ke-tiga & 46 & 22.00 \\
Ke-empat & 13 & 6.25 \\
Ke-lima & 2 & 0.95 \\
Ke-tujuh & 1 & 0.47 \\
\hline
\end{tabular}

Pada tingkat pendapatan orang tua pada dalam penelitian ini, yang memiliki tingkatan pendapaan $<1000.000$ berjumlah 13orang atau $6 \%$, pendapatan pada rentang 1000.000-2000.000 berjumlah 67 orang atau $32 \%$, pendapatan pada rentang 3000.000-4000.000 berjumlah 74 orang atau 36\%, pendapatan pada rentang 5000.000-6000.000 berjumlah 30 orang atau $14 \%$, dan pendapatan pada rentang $>7000.000$ berjumlah 25 orang atau $12 \%$. Selanjutnya data orang tua bersadarkan keikutsertaan support group, partisipan yang mengikuti support group berjumlah114 orang atau 55\%, sementara itu partisipan penelitian yang tidak mengikuti support group terdapat 95 orang atau $45 \%$.

\section{Hasil Uji Hipotesis Analisis Regresi}

Tabel 2

$R$-Square

Model Summary

Model $\mathbf{R}$ R Square Adjusted R Square Std. Error of the Estimate

\begin{tabular}{llll}
\hline 1 & $.537^{\mathrm{a}} .288$ & .260 & 7.56948 \\
\hline
\end{tabular}


a. Predictors: (Constant), Income, Kegiatan_keagamaan_kelompok, Support_group, Self_compassion, Pengalaman_keagamaan, Kegiatan_keagamaan_individu, Pengetahuan_Keagamaan,

Keyakinan_Keagamaan

Berdasarkan data pada tabel $R$-Squarediketahui bahwa perolehan $R$-square sebesar 0.288 atau $28.8 \%$. Artinya proporsi varians dari Subjective well-being yang dijelaskan oleh independent variable sebesar $28.8 \%$, sedangkan $71.2 \%$ dipengaruhi oleh variabel lain di luar penelitian ini.

\section{Anova Keseluruhan IV terhadap DV}

\section{Tabel 3}

Anova

ANOVA $^{\mathrm{a}}$

\begin{tabular}{lccccc}
\hline Model & Sum of Squares & df & Mean Square & F & Sig. \\
\hline Regression & 4644.621 & 8 & 580.578 & 10.13 & $.000^{\text {b }}$ \\
1 Residual & 11459.418 & 200 & 57.297 & & \\
$\quad$ Total & 16104.038 & 208 & & & \\
\hline
\end{tabular}

a. Dependent Variable: SWB

b. Predictors: (Constant), Income, Kegiatan_keagamaan_kelompok, Support_group, Self_compassion, Pengalaman_keagamaan, Kegiatan_keagamaan_individu, Pengetahuan_Keagamaan, Keyakinan_Keagamaan

Berdasarkan tabel anova diketahui bahwa nilai $\mathrm{p}$ (sig) pada kolom paling kanan adalah sebesar 0,000 atau dengan nilai $p<0,05$. Dengan demikian hipotesis yang menyatakan terdapat pengaruh yang signifikan dari seluruh independent variable terhadap subjective well-being diterima, artinya terdapat pengaruh yang signifikan dari Self-compassion, Pengetahuan keagamaan, keyakinan keagamaan,kegiatan keagamaan kelompok, kegiatan keagamaan individu pengalaman keagamaan, support group, dan Pendapatan terhadap subjective wellbeing.

Tabel 4

Koefisien Regresi masing-masing IV

\begin{tabular}{llccccc}
\hline \multicolumn{2}{c}{ Model } & \multicolumn{2}{c}{ Un-Std Coeff } & Std Coeff & \multirow{2}{*}{ t } & \multirow{2}{*}{ Sig. } \\
\hline $1 \quad$ (Constant) & 13.540 & 4.234 & & 3.198 & .002 \\
& SC & .127 & .064 & .133 & 1.986 & .048 \\
& Pngetahuan A & .234 & .104 & .216 & 2.251 & .025 \\
Keyakinan A & -.035 & .097 & -.035 & -.362 & .718 \\
& Kegiatan A Kel & -.032 & .091 & -.032 & -.352 & .725 \\
& Kegiaan A Ind & .107 & .105 & .098 & 1.019 & .309 \\
& PengalamanA & .268 & .103 & .251 & 2.619 & .010 \\
& Suport group & .040 & 1.058 & .002 & .037 & .970 \\
& Pendapatan & 1.024 & .495 & .127 & 2.070 & .040 \\
\hline
\end{tabular}

Berdasarkan tabel koefisien regresi, dapat diketahui bahwa terdapat empat variabel yang signifikan mempengaruhi subjective well-being, yaitu Self-compassion 
dengan signifikansi 0.048,pengetahuan keagamaan dengan signifikansi 0.025 , pengalaman keagamaan dengan signifikansi 0.010 dan pendapatan dengan signifikansi 0.040 .

\section{Proporsi Varians}

Untuk melihat penambahan proporsi varian tiap variabel independen terhadap subjective well-being. Terdapat delapan variabel terdapat 8 variabel yang dapat dilihat proporsinya yaitu:

1. Variabel self-compassion memiliki $R$ Square Change sebesar 0.091, yang berarti bahwa aspek ini memiliki kontribusi terhadap SWB sebesar $9.1 \%$ dan sumbangan tersebut signifikan secara statistik karena nilai Sig. F Change $=0.000(p<0.05)$.

2. Variabel pengetahuan keagamaan memiliki $R$ Square Change sebesar 0.112 , yang berarti bahwa aspek ini memiliki kontribusi terhadap SWB sebesar 11.2\% dan sumbangan tersebut signifikan secara statistik karena nilai Sig. F Change $=0.000(\mathrm{p}<0.05)$.

3. Variabel keyakinan keagamaan memiliki $R$ Square Change sebesar 0.023 , yang berarti bahwa aspek ini memiliki kontribusi terhadap SWB sebesar $2.3 \%$ dan sumbangan tersebut signifikan secara statistik karena nilai Sig. F Change $=0.015(p<0.05)$.

4. Variabel kegiatankeagamaan kelompok memiliki $R$ Square Change sebesar 0.000 , yang berarti bahwa aspek ini memiliki kontribusi terhadap SWB sebesar $0 \%$ dan sumbangan tersebut tidak signifikan secara statistik karena nilai Sig. F Change $=0.972(p>0.05)$.

5. Variabel kegiatankeagamaan individu memiliki $R$ Square Change sebesar 0.018, yang berarti bahwa aspek ini memiliki kontribusi terhadap SWB sebesar 1.8\% dan sumbangan tersebut tidak signifikan secara statistik karena nilai Sig. F Change $=0.029(p>0.05)$.

6. Variabel pengalaman keagamaan memiliki $R$ Square Change sebesar 0.030, yang berarti bahwa aspek ini memiliki kontribusi terhadap SWB sebesar 3\% dan sumbangan tersebut signifikan secara statistik karena nilai Sig. F Change $=0.004(\mathrm{p}<0.05)$.

7. Variabel support group memiliki $R$ Square Change sebesar 0.000 , yang berarti bahwa aspek ini memiliki kontribusi terhadap SWB sebesar $0 \%$ dan sumbangan tersebut tidak signifikan secara statistik karena nilai Sig. F Change $=0.898(\mathrm{p}>0.05)$.

8. Variabel income memiliki $R$ Square Change sebesar 0.015 , yang berarti bahwa aspek ini memiliki kontribusi terhadap SWB sebesar $1.5 \%$ dan sumbangan tersebut signifikan secara statistik karena nilai Sig. F Change $=0.040(p<0.05)$.

\section{KESIMPULAN, DISKUSI, DAN SARAN}

\section{Kesimpulan}

Setelah dilakukan uji hipotesis pada bab hasil, maka pada hipotesis mayor yang menjadi kesimpulan dari penelitian ini adalah: "ada pengaruh yang signifikan secara bersama-sama dari self-compassion, religiusitas (pengetahuan keagamaan, keyakinan keagamaan,kegiatan keagamaan kelompok, kegiatan keagamaan 
individu, pengalaman keagamaan), support group dan pendapatan terhadap subjective well-being orang tua yang memiliki anak tunagrahita". Hal ini di dasarkan atas hasil uji $\mathrm{F}$ yang menguji keseluruhan variabel independen terhadap variabel dependen. Perolehan $R$ square sebesar 0.288 atau $28.8 \%$ menujukan proporsi varian variabel independen yang dapat mempengaruhi variabel dependen, sedangkan $71.2 \%$ dipengaruhi oleh variabel lain di luar penelitian.

Namun pada hipotesis minor yang menguji pengaruh setiap variabel independen terhadap variabel dependen, jika dilihat dari signifikan tidaknya koefisien regresinya, ditemukan bahwa terdapat empat variabel independen yang memiliki koefisien regresi yang signifikan. Variabel tersebut adalah selfcompassion,religiusitas di aspek pengetahuan keagamaan dan pengalaman keagamaan), dan pendapatan rumah tangga partisipan penelitian. Sedangkan variabel religiusitas di aspek keyakinan keagamaan, kegiatan keagamaan kelompok, kegiatan keagamaan individu juga variabel support group tidak memiliki pengaruh yang signifikan terhadap subjective well-being orang tua yang memiliki anak tunagrahita.

\section{Diskusi}

Penelitian ini dilakukan bertujuan untuk melihat pengaruh variabel selfcompassion, religiusitas, support group, dan pendapatan terhadap subjective well-being orang tua yang memiliki anak dengan tunagrahita. Pada hasil penelitian ditemukan variabel self-compassion memiliki pengaruh positif yang signifikan terhadap subjective well-being. Temuan ini sejalan dengan penelitian Neff mengenai hubungan self-compassion dan well-being orangtua yang memiliki anak autis. Di dalam temuan penelitian dinyatakan bahwa tingginya level self-compassion dalam diri orang tua dihubungkan dengan baiknya kondisi kesejahteraan orang tua yang memiliki anak autis. Disebutkan juga bahwa self-compassion dapat menjadi penawar dan character strength pada personal distress yang kerap kali muncul pada orangtua yang memiliki anak autis (Neff,2014).

Self-compassion berperan sebagai regulasi emosi terhadap suatu kejadian yang tidak diinginkan dalam hidup. Seseorang di dorong untuk menanggapi suatu kejadian dengan penuh kesadaran akan pemahaman diri dan situasi, pemakluman, dan penerimaan yang dimaknai sebagai sebuah pelajaran hidup (Neff, 2011). Sehingga atas proses self compassion tersebut dapat membentuk perspektif baru yang lebih baik terhadap kejadian yang dialami (Neff, 2004). Mengalami kejadian yang tidak diiginkan diumpamakan dalam penelitian adalah orang tua yang memiliki anak dengan tunagrahita. Memang rasa berat untuk menerima adalah suatu hal yang sulit dilakukan, Namun dengan menerapkan selfcompassion maka akan terbentuk pemahaman, pemakluman dan penerimaan yang lebih cepat sehingga orang tua dapat memiliki perspektif baru yang lebih baik di mana hal tersebut adalah indikasi dari tingginya subjective well-being dalam diri orang tua.

Pada penelitian ini peneliti menggabungkan seluruh dimensi selfcompassion(self-kindness, common humanity, dan mindfulness) menjadi variabel besar karena berdasarkan penjalasan teori Neff dimensi variabel ini bersifat saling melahirkan satu sama lain, sehingga dalam pengukurannya akan lebih 
komprehensif dan berpotensi memberikan sumbangan yang berpengaruh signifikan pada subjective well-being orang tua yang memiliki anak tunagrahita.

Kemudian pada variabel religiusitas pengaruh yang diberikan lebih besar dibanding kontribusi variabel lainnya terhadap variabel dependen. Hal ini mencerminkan aspek religiusitas sangat berpengaruh khususnya dalam aspek pengetahuan keagamaan dan pengealaman keagamaan dalam meningkatkan subjective well-being orangtua yang memiliki anak tunagrahita. Temuan ini sejalan dengan penelitian Diener mengenai pengaruh religiusitas terhadap subjective wellbeing pada level nasional menunjukan responden dengan tingkat religiusitas yang tinggi mengakibatkan tingginya tingkat subjective well-being pada orang-orang yang memiliki kehidupan yang sulit (Diener, Tay,Myers, 2010).

Religiusitas menjadi faktor penting dalam subjective well-being, karena terdapat banyak fakta yang menyatakan bahwa dampak dari keterikan agama adalah diperolehnya emosi positif dalam diri individu. Pengaruh religiusitas dalam banyak penelitian juga semakin kuat terhadap subjective well-being ketika di latar belakangi oleh keadaan yang sulit ( Diener et.al ; Diener et.al 2014). Hal itu ditemukan karena keadaan sulit membuat religiusitas seseorang semakin kuat. hal itu dapat dipahami orang tua yang memiliki anak dengan tunagrahita di hadapkan pada banyak pemicu stres yang tinggi dapat menjadi lebih religius, sehingga mengakibatkan hadirnya emosi positif dan pandangan hidup yang lebih baik.

Peneliti juga menemukan penelitian religiusitas khususnya pada partisipasi kegiatan ibadah dari temuan hasil penelitiannya menyatakan bahwa partisipasi keagamaan mempengaruhi secara negatif terhadap subjective well-being orang dewasa di Cina. Masih dalam penjelasan penelitiannya hal tersebut bisa diakibatkan oleh variabel yang tidak terkontrol dalam penelitian misalnya agama yang dianut, tipe aktifitas keagamaan dan intensitas aktifitas keagamaan (Philip $\mathrm{H}$ brown \& brian tierney, 2006). Sama hal nya dengan penyebab tidak signifikan pengaruh religiustas di aspek keyakinan keagamaan dan kegiatan keagamaan baik individu maupun kelompok pada penelitian ini peneliti duga akibat variabel yang tidak terkontrol di dalam penelitian.

Selanjutnya, dalam penelitian ini terdapat dua variabel demografis yang ikut diukur, yaitu support group dan pendapatan. Berdasarkan hasil pengolahan data di bab sebelumnya, didapatkan bahwa variabel support group tidak berpengaruh secara signifikan terhadap subjective well-being.

Temuan penelitian ini bertolak belakang dengan penelitian Yoon yang menyatakan adanya pengaruh yang kuat antara social connectedness terhadap subjective well-being pada orang dewasa yang mengikuti komunitas imigran korea dibanding mereka yang tidak mengikuti komunitas imigran (Yoon \& Lee, 2010).

Hal ini dapat disebabkan oleh perbedaan sampel di mana karakteristik orang dewasa dalam penelitian tersebut tidak terkhusus pada orang tua yang memiliki anak tuna grahita, hal lain yang juga dapat menjelaskan adalah kehidupan yang di jalani oleh orang tua yang memiliki anak tunagrahita tidak bisa di bandingkan dengan orang deawasa yang tidak dihadapan kondisi demikian, namun dalam hal ini peneliti memfokuskan variabel penelitian yang sama pada peran support group yakni komunitas imigran terhadap subjective well-being . 
Selain itu tidak berpengaruhnya support group dalam penelitian ini bisa disebabkan oleh belum terbentuknya hubungan yang secure antara orang tua yang mengikuti support group. Oleh sebab itu kebermanfaatan support group belum begitu terasa sehingga belum mampu menjadi faktor yang bisa meningkatan subjective well-being dalam diri orang tua. Selain itu beragamnya aspek social support di luar support group yang dapat menjadi faktor meningkatnya subjective well-being seperti keluarga, tetangga, teman, dukungan pengahargaan, dukungan formatif dan lain sebagainya, sehingga faktor-faktor dukungan sosial di luar support group tersebut dapat membuat orang tua yang tidak beraprtisipasi dalam support group memiliki tingkat subjective well-being yang tinggi.

Sementara itu dalam penelitian Tessen Clifford (2014) yang berjudul "Support groups for Parents of Children with Autism Spectrum Disorders: Predictors and Effects of Involvement" menyatakan orang tua yang berpartisipasi aktif pada parents support group (PSG) memiliki tingkat kepuasan atas kebermanfaatan grup yang lebih tinggi dan penggunaan coping yang lebih adaptif di banding orang tua yang tidak pernah mengikuti PSG dan orang tua yang memutuskan tidak melanjutkan keikutsertaan dalam PSG. Dilaporkan juga bahwa orang tua yang memutuskan untuk tidak melanjutkan keikutsertaan dalam PSG disebabkan karena, rendahnya dukungan dari orang-orang yang diinginkan dalam grup, sehingga orang tua merasa tidak mendapatkan manfaat seperti yang di rasakan orang tua yang berpartisipasi aktif (Clifford, 2011). Berdasarkan pemaparan penelitian tersebut dapat diambil beberapa alasan mengapa support group dalam penelitian ini belum mampu meningkatan subjective well-being orang tua yang memiliki anak tunagrahita.

Variabel pendapatanmemberikan kontribusi yang signifikan dalam peningkatan subjective well-being orang tua yang memiliki anak tunagrahita. Temuan ini sesuai dengan penelitian subjective well-being oleh Eprika Adhityani (2014) yang menggunakan populasi orang tua yang memiliki anak autis di Jakarta. Dalam temuan penelitiannya menyatakan bahwa variabel pendapatan berpengaruh secara signifikan terhadap subjective well-being pada orang tua yang memiliki anak autis. Masih dalam penelitiannya Eprika juga menjelaskan bagi orang tua yang memiliki anak Autism spectrum disoerder beban finansial yang tidak sedikit untuk membiayai pelayanan anaknya dapat menjadi pemicu tingginya distress pada orang tua. Dengan adanya pendapatan (pendapatan keluarga) yang tinggi, maka biaya finansial tidak lagi menjadi satu kendala bagi orang tua dan tentu akan mempermudah para orang tua untuk mendapatkan berbagai macam treatment yang tepat untuk anaknya (Adhityani, 2014).

Tidak bisa dipungkiri memiliki anak dengan kebutuhan spesial membutuhkan perlakuan dan kebutuhan khusus. Kebutuhan akan sekolah khusus, makanan khusus, therapy yang dapat menstimulasi life skill anak, dan lain sebagainya. kebutuhan khusus anak tersebut dapat terpenuhi dengan baik ketika ditunjang dengan kondisi keuangan yang memadai. Dalam sebuah penelitian ditemukan bahwa pendapatanakan meningkatkan subjective well-being seseorang, selama pendapatandapat membantu seseorang dalam memenuhi kebutuhan dasarnya (Diener\& biswas,2001). Oleh karena itu semakin baiknya kondisi 
keuangan orang tua yang memiliki anak tunagrahita akan memudahkan orang tua dalam memenuhi kebutuhan baik anak maupun keluarga.

\section{Saran}

Hasil penelitian ini dapat menjadi masukan positif bagi orang tua yang memiliki anak tunagrahita untuk dapat memperhatikan faktor-faktor yang dapat mempengaruhi subjective well-being nya.

Dengan berpengaruhnya variabel self-compassion terhadap subjective well-being diharapkan orang tua dapat menyadari pentingnya menghadirkan karakter ini dalam kehidupan. Selain itu juga memperkaya diri dengan ilmu pengetahuan agama dan memaknai setiap kejadiaan secara postif agar terjagaanya kondisi subjective well-being orang tua dalam kehidupan sehari-hari bersama anaknya yang spesial.

Diharapkan juga pemerintah dan instansi terkait dapat mengadakan bimbingan penyuluhan kepada orang tua yang memiliki anak tunagrahita tentang makna postif akan kehadiran anak dengan tunagrahita di tengah-tengah kehidupan keluarga.

\section{DAFTAR PUSTAKA}

Abdullah, N. (2013). Mengenal Anak Berkebutuhan Khusus. MAGISTRA, 5(86), $1-10$.

Adhityani, E. (2014). Pengaruh Optimisme,Religiusitas, dan Dukungan Sosial Terhadap subjective well-being orang tua yang memiliki anak ASD Autism Spectrum Disorder). Universitas Islam Negeri Syarif Hidayatullah Jakarta, 1-20.

Ahuvia, A. C., \& Friedman, D. C. (1998). Income, consumption, and subjective well-being: Towar a composite macro marketing model. Journal of macromarketing, 18(2), 153 168.doi:10.1177/0276146798018 0207.

Anggraini, R. R. (2011). Persepsi Orang tua Terhadap Anak Berkebutuhan. Jurnal Ilmiah Pendidikan Khusus vol.1,2013,Pg 258-265.

Benjak, T., Vuletić Mavrinac, G., \& Pavić Šimetin, I. (2009). Comparative Study on Self perceived Health of Parents of Children with Autism Spectrum Disorders and Parents of Nondisabled Children in Croatia. Croatianmedical journal, 50(4), 403-409. doi: 10.3325/cmj.2009.50.403.

Boromand, N., Narimani, M., \& Mosazadeh, T. (2014). Comparing the psychological well being factors among the parents of the mentally retarded children with those of the normal children. International Letters of Social and Humanistic Sciences, (21), 1-8.. doi: 10.18052/www.scipress.com

Calvisi, D., \& Dibble, J. (2011). Well-being in older adults in three different. Grand Valley State University Volume 32, 2016.

Clifford, T. (2011). Support groups for Parents of Children with Autism Spectrum Disorders: Predictors and . thesis, 35. Colón-Bacó, E. (2010). The strength of religious beliefs is important for subjective well-being. Undergraduate economic review, 6(1), 11.Retrieved fromhttp://digitalcommons.iwu.edu/uer/vol6/iss1/11 
Cramm, J.M, \& Nieboer, A.P. (2011). Psychological well-being of caregivers of children with intellectual disabilities: Using parental stress as a mediating factor. Journal of Intellectual Disability Research, 15(2), 101-113. doi:10.1177/1744629511410922

Degutis, M., \& Urbonavicius, S. (2013). Determinants of subjective wellbeing in Lithuania. Engineering Economics, 24(2), 111-118. doi:10.1007/s11136 014-0694-8

Desmet, P. M. A., \& Pohlmeyer, A. E. (2013). Positive design: An introduction to design for subjective well-being. International Journal of Design, 7(3), 5-19

Diener, E. (1984). Subjective well-being. Psychological bulletin Vol. 95, No. 3, 1984, $542-565$.

Diener, E., Suh, E. M., Lucas, R. E., \& Smith, H. E. (1999). Subjective wellbeing: Threedecades of progress. Psychological Bulletin, 125, 276, 302.

Diener, E., Oishi, S., \& Lucas, R. E. (2009). Subjective well-being: The science of happiness and life satisfaction. Oxford handbook ofpositive psychology, 2, 187194.

Diener, E., \& Chan, M. Y. (2011). Happy people live longer: Subjective well-being contributes to health and longevity. Applied Psychology: Health and Well-Being, 3(1), 1 43. doi: 10.1111/j.1758 0854.2010.01045.x

Diener, E., Tay, L., \& Oishi, S. (2013). Rising income and the subjective well being of nations. Journal of personality and social psychology, 137, 267.doi: $10.1037 / \mathrm{a} 0030487$

Drakulić, A. M. (2012). A phenomenological perspective on subjective wellbeing: From myth to science. Psychiatria Danubina, 24(1.), 31-37.

English, E. (2013). The effect of community participation on subjective well-being in community dwelling elders. Honors Projects, 1-22.

Hall, C. W., Row, K. A., Wuensch, K. L., \& Godley, K. R. (2013). The role of self compassion in physical and psychological well-being. The Journal of psychology, 147(4), 311-323.

Huber, S., \& Huber, O. W. (2012). The centrality of religiosity scale (CRS). Religions, 3(3), 710, 724.doi:10.3390/rel3030710

Jacobson, J. W., Mulick, J. A., \& Rojahn, J. (2007). Handbook of Intellectual and Develpmental Disability. New York: Springer Science+Business Media.

Luhmann, M., Hofmann, W., Eid, M., \& Lucas, R. E. (2013). Subjective well-being and Adaptation to Life Events: A Meta-. J Pers Soc Psycho, 3, 592-615. doi: $10.1037 / \mathrm{a} 0025948$

Matson, J. L. (2007). Handbook of Assessment in Persons with Intellectual Disability. Baton Rouge, Louisiana: Elsevier Inc.

Mattson, M., \& Gibb, H. J. (2011). Linking health communication with social support. in:Health as Communication nexus: A Service-learning approach. Dubuqu: Kendall Hunt Publishing Company.

Neff, K. D. (2003). The development and validation of a scale to measure selfcompassion. Self and identity, 2(3), 223-250 Volume 2, 2003.

Neff, K. (2003). Self-compassion: An alternative conceptualization of a healthy attitude toward oneself. Self and identity, 2(2), 85-101. 
Neff, K. D. (2004). Self-compassion and psychological well-being Constructivism in the human sciences, 9(2), 27-37.

Neff, K. D. (2011). Self-compassion, self-esteem, and well-being. Social and personality psychology compassion, 5(1), 1-12.

Neff, K. D. (2012). The science of self compassion. In C. Germer \& R. Siegel (Eds.), Compassion and Wisdom in Psychotherapy. 79-92

Neff, K. D., \& Faso, D. J. (2015). Self compassion and well-being in parents of children with autism. Mindfulness, 6(4), 938, 947.doi:10.1007/s12671-014 $0359-2$

Neff, K. D. (2016). The self-compassion scale is a valid and theoretically coherent measure of self compassion. Mindfulness, 7(1), 264, 274. $10.1007 / \mathrm{s} 12671$ 015-0479-3

NICHCY. (2011, january). Parent to Parents Support. 3nd edition, p. 2.

Nikmat, A. W., Ahmad, M., Oon, N., \& Razali, S. (2008). Stress and psychological wellbeing among parents of children with autism spectrum disorder. ASEAN Journal of Psychiatry, 9(2), 65-72.

Mbugua, M. N., Kuria, M. W., \& Ndetei, D. M. (2011). The prevalence of depression among family caregivers of children with intellectual disability in a rural setting in Kenya. International journal of family medicine, 2011. doi: $10.1155 / 2011 / 534513$

O'Hara, J., McCarthy, J., \& Bouras, N. (2010). Intellectual Disability and Ill Health. Cambridge: Cambridge University Press.

Pahlevi, Reza. (2016). Terbukti... "Down Syndrome" Tak Benamkan Mimpi Stephanie!. Diunduh tanggal 12 April 2016 dari KOMPAS.COM: http://edukasi.kompas.com/read/206/02/25/12390031/Terbukti.Down Syndrome.Tak.Benamkan.Mimpi. stephanie.

Paloutzian, R., \& Santrock, J. (2005). Handbook Of the Psychology of Religion and Spirituality. London: The Guildford Press.

Parnami, M., Mittal, U., \& Hingar, A. (2013). Impact of religiosity on subjective well-being in various groups: A comparative study. Indian Journal of Health and Wellbeing, 4(4), 903908.

Pavot, W., \& Diener, E. (1993). Review of the satisfaction with life scale Psychological assessment, 5(2), 164 172.doi: 10.1007/s11205 012-0076-

Raina, P., O'Donnell, M., Rosenbaum, P., Brehaut, J., Walter, S. D., Russell, D., \& Wood, E. (2005). The health and well-being of caregivers of children with cerebral palsy. Pediatrics, 115(6), 626-636. doi: 10.1542 /peds.2004-1689

Republik Indonesia. 1945. Undang-Undang Dasar Tahun 1945 Pasal 31 ayat 1 Tentang Hak dan Kewajiban dalam Pendidikan dan Kebudayaan. Jakarta : Negara Republik Indonesia.

Republik Indonesia. 2011. Undang-Undang No 10 Tahun 2011 Tentang Kebijakan Penanganan Anank Berkebutuhan Khusus. Jakarta Menteri Negara Pemberdayaan Perempuan dan Perlindungan Anak.

RIMANEWS. (2014). Perjuangan Ibu Bersama Anak-anak Berkebutuhan Khusus. Diunduh tanggal 6 Maret 2016 dari RIMANEWS: 
http://rimanews.com/read/20140226/144883/perjuangan-ibu-bersamaanak-anak-berkebutuhan-khusus

Ritzema, A. M., \& Sladeczek, I. E. (2011). Stres in Parents of Children with Developmental Disabilities over Time. Journal on Developmental Disability, 27,21-34. doi:10.1111/j.1365-2788.2006.00933

Sudjana, I. (2011, Agustus Senin). Sosial Budaya. Diunduh tanggal 7 Maret 2016 dari Bale Bengong: http://balebengong.net/kabar anyar/2011/08/15/anak-saya-autis-tapi-dia-.

Umar, J. (2011). Analisis konfirmatori. Bahan ajar peminatan psikometri, Tidak di Publikasikan. $=$ Fakultas Psikologi Universitas Islam Syarif Hidayatullah Jakarta.

Watson, D., Pichler, F., \& Wallace, C. (2010). Subjective well-being in Europe. Luxembourg: Office for Official Publications of the European Communities.

Werner, S., \& Shulman, C. (2013). Subjective well-being among family caregivers of individuals with developmental disabilities: the role of affiliate stigma and psychosocial moderating variables. Research in Developmental Disabilities, $34 \quad$ (11), 4103-4114. doi:http://dx.doi.org/10.1016/j.ridd. 01308.029

Wolbring, G. (2013). Subjective wellbeing, body-related ability expectations andpeace. International Journal of Peace Studies, 29-42.

Yoon, E., \& Lee, R. M. (2010). Importance of Social Connectedness as a Moderator in Korean Immigrants Subjective Well-being. Asian American Journal of Psychology, 93-105. doi:10.1037/a0019964. 
Pengaruh Self-Compassion, Religiusitas, Support Group \& Pendapatan terhadap Subjective Well-Being Orang Tua Anak ... 